\title{
THE ADOPTION OF SERVQUAL METHOD TO ANALYZE THE QUALITY ASSURANCE FACTORS OF PERSONAL PROTECTIVE EQUIPMENT FOR HEALTH CARE WORKERS
}

\author{
Bartosz ORZEŁ ${ }^{1 *}$, Anna Maria HORODECKA ${ }^{2}$ \\ ${ }^{1}$ Silesian University of Technology, Faculty of Organisation and Management, Department of Economics and \\ Computer Science; bartosz.orzel@polsl.pl, ORCID: 0000-0003-1506-4798 \\ ${ }^{2}$ Silesian University of Technology, Faculty of Organisation and Management, Department of Logistics and \\ Management; anna.horodecka@polsl.pl, ORCID: 0000-0001-9853-3806 \\ * Correspondence author
}

Purpose: The purpose of article is to perform the analysis method based on SERVQUAL method, which will allow us to analyze and asses factors connected to quality assurance of health care workers' personal protective equipment and its level.

Design/methodology/approach: The main objective is to present method of data collection. It should be achieved by using a SERVQUAL method adoption to create a set of questions, which can be directed to medical and health care workers. The main method used in research is questionnaire. Scores from it can be useful for further statistical analysis. The approach on this stage of research is theoretical.

Findings: The main finding is create useful questionnaire, which can be helpful to analyze and asses factors and level of quality assurance of health care workers' personal protective equipment (PPE). The other one is to use GAP method to discover 5 gaps in PPE delivery to health care workers in Polish medical facilities.

Research limitations/implications: This paper presents only adopted to research in PPE quality of health care workers SERVQUAL method and the build of questionnaire (survey), which will be useful to next researches and statistical analysis It will be introduce in future, however the proposition of action path was shown in this paper.

Practical implications: A useful questionnaire can be implicate in broader understood improvement of health care workers' personal protective equipment quality. This questionnaire should allow us to analyze and define, which elements of equipment are mostly limited and need in Polish health care institutions such as hospitals, clinics etc.

Social implications: The main positive result is define what is necessary to improve and assure good quality and safety in COVID-19 pandemic times both for health care workers and patients. Introducing of further suggested actions can help to minimize risk of infection, which can contribute to improving the sense of security and social order in these times.

Originality/value: This paper touches important in COVID-19 pandemic times issues, which are connected to health care workers safety and hence for all society.

Keywords: SERVQUAL, method, health care, COVID-19, medical, equipment.

Category of the paper: conceptual paper, literature review. 


\section{Quality assurance of health care workers' personal protective equipment importance}

In order to emphasize the importance of the personal protection of health care workers, it is necessary to go back to the Middle Ages. Even then, and much earlier, special safeguards were applied during contact with sick people, especially during epidemics and pandemics, which were so often affected medieval cities, and even devastated entire countries. Both in these times and nowadays, the importance of personal protective is the same. Medical knowledge and technical development allow us to recognize biohazard and take up activities to reduce it. Nevertheless, knowledge, technical development and ability to recognize it, often does not go with practical following medical procedures, their implementation and taking precautionary measures. This issue is of particular importance in times of COVID-19 pandemic. Personal protective equipment (PPE) is a tool that allows healthcare professionals to perform their work both in Poland and around the world due to minimalize risk of infection. PPE is absolute base of contact ability with infected patients, people in risk groups, during researches conducted in laboratories and also everyday performance of professional duties. This paper shows the concept of data gathering and proposal of further proceed for measure of the quality level of personal protective equipment of health care workers in Polish health care institutions during the COVID-19 pandemic. This data- gathering method is necessary to PPE quality level measure and assessment. It is based on SERVQUAL method. Taking the form of a questionnaire, it addresses a set of questions related to the issues of general safety in health care institutions and personal protection equipment of their workers directly to them.

\section{SERVQUAL Method, GAP model and a term of "quality"}

SERVQUAL (Services Quality) is the method of quality assessment, which was developed by American scientists team at University in Miami. SERVQUAL method and its model is useful tool for identifying customers' demands (Prentkovskis et al., 2018). Its origins are related to the GAP model developed in 1985 by Parasuraman, Zeithaml and Barry. The GAP model consists of 5 gaps, which performing is connected to decrease of services and products quality. Additionally, the GAP model combines quality of services designing from customer's point of view and organisation's perception of customer's expectations (Urbaniak, 2013; Hsu et al., 2018; Gronroos, 1988). The GAP model of services quality with 5 gaps was shown below (Figure 1). 


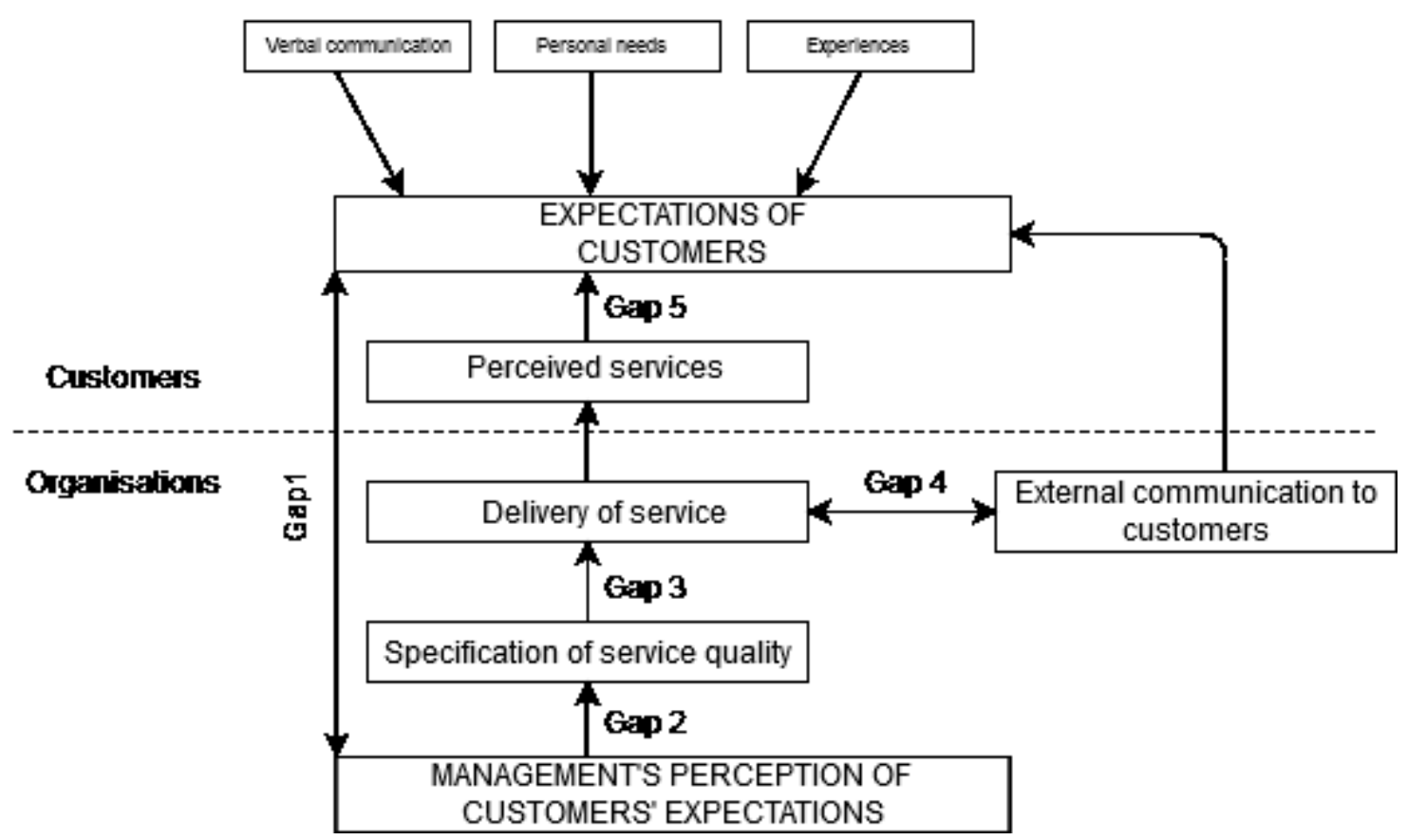

Figure 1. The GAP model of services quality with 5 gaps. Adapted from: Stasiak-Betlejewska, R., Kaye, M., Dyason, M., Stachová, K., Urbancová, H. (2014). The services quality level assessment at the technical university using the SERVQUAL method, ERIES Journal, 7,3-4, 53-58 doi:10.7160/eriesj.2014.070302

The five gaps, which was shown above are: (Guerguis, 2018; Wolniak, and SkotnickaZasadzień, 2009)

- Gap 1: not meeting the expectations of the consumer and how it was received and perceived by the organisation,

- Gap 2: inconsistencies and inadequate quality standards in the organisation, which lead to misunderstanding of customer expectations and their incorrect perception by managers,

- Gap 3: service performance gap, meaning a discrepancy between the internal standards and quality specifications of the services provided by the organisation and the actual level of their quality,

- Gap 4: differences in the way of communicating about the quality of provided services and the actual quality of the process of their provision. The promises do not meet the consumer's expectations regarding the service delivery,

- Gap 5: the difference between how customers perceive is the service they received and what they received,

An original version of SERVQUAL is based on 2 parts. The $1^{\text {st }}$ one is 22 items part, which role is to measure customers' expectation of companies in particular sector. The $2^{\text {nd }}$ one is also consists of 22 items and its role is to measure customer's perception of company in this sector (Parasuraman et al., 1991; Kar, 2016). Therefore, the original version of SERVQUAL is approaching to the topic of service quality from importance of different factors, expectations and gaps (Kaldenberg et al., 2019; Tavakoli et al., 2019). There is also exists a version of 
SERVQUAL method, which omits the expectation part, assuming that expectations are always maximal. This type of this method is called SERVPERF (Wolniak, 2010). Such variation of SERVQUAL Method can be useful during comparing results of research with using this method and its variations (Banahene et al., 2017). The term "services" can be described as "service is appliance of particular capabilities, via distinct procedures to assist individuals" (Sheikh, and Waqas, 2019).

Inextricably linked with the SERVQUAL method and services is quality. The term "quality" can be mean as "all properties of the object related to its ability to meet the identified and expected needs" (Hamrol, and Mantura, 2002). This definition suggests that quality is the total sum of factors, which are able to satisfy customers' needs. The other definitions tell: quality is meeting the expectations of recipients, the quality is determined by the set of service features, allowing for the satisfaction of assumed and planned needs (Urbaniak, 2013; Abramov, 2011). From the other hand "service quality is seen as an important factor that affects client satisfaction and behavioral intention. It is considered as business success important contributors (Sunindijo, and Bonaventura, 2014). The result of researches suggests that when functional quality of service is perceived as superior by consumers, the employees of a service business are more trusted (Chang et al., 2013). In the case of providing PPE quality for health care workers the "quality" means both performing factors, which will cause that risk of work in high risk environment will be correspondingly low and it will be translated into a sense of security and comfort. This makes that the medical services will be perform in a satisfactory, effective and first of all, safe manner also for patients. In medical staff services there are 5 major dimensions: (Lestari, and Setyawan, 2019; Ko, and Chou, 2020)

- Reliability,

- Assurance,

- Tangible,

- Empathy,

- Responsiveness.

\section{A GAP model adoption to analyze PPE quality factors and create based on SERVQUAL method questionnaire}

Therefore, it can be concluded that by adopting a GAP model to personal protection quality factors analysis, health care workers become clients. The medical facility and its authorities/owners become an organisation. Below the GAP model of services adopted to described situation was shown (Figure 2). 


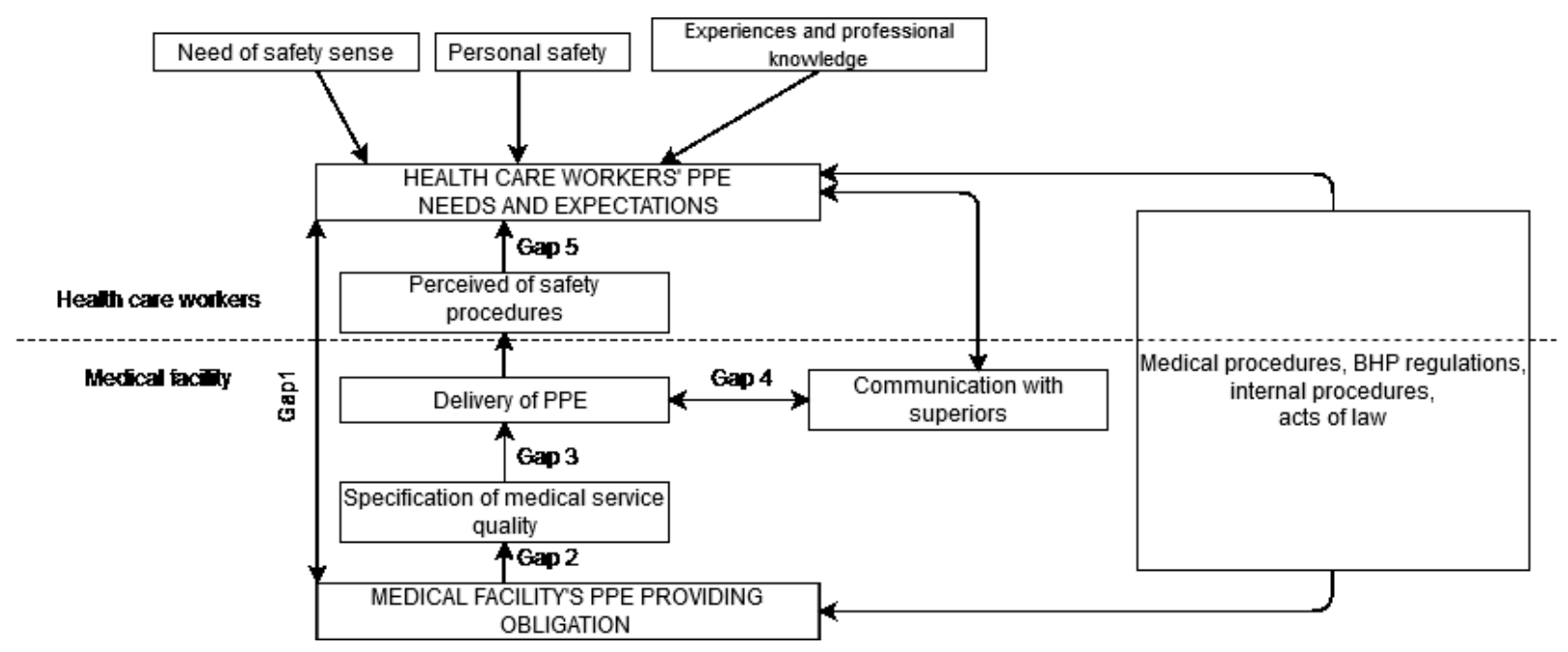

Figure 2. The GAP model of PPE quality assurance for health care workers. Own work based on: Stasiak-Betlejewska, R., Kaye, M., Dyason, M., Stachová, K., Urbancová, H. (2014). The Services quality level assessment at the technical university using the SERVQUAL method, ERIES Journal, 7, 3-4, 53-58 doi:10.7160/eriesj.2014.070302.

Looking holistically at this model, it would be necessary to include also patients who could be treated as a separate group of clients. It would be necessary to examine the impact of the personal protective equipment usage by health care workers on the sense of patients' safety and their satisfaction with the medical services provided. However, this is not the subject of this paper. According to presented on Figure 2, 5 gaps in PPE quality assurance for health care workers could be described as:

- gap 1: not meeting the expectations of the workers and how it was received and perceived by the medical facility,

- gap 2: inconsistencies and inadequate quality standards in the organisation, which lead to misunderstanding of workers expectations, non-compliance with medical procedures and their incorrect perception by authorities/owners of facility,

- gap 3: service performance gap, meaning a discrepancy between the internal standards and personal protection procedures and quality specifications of the services provided by the organisation and the actual level of their quality,

- gap 4: differences in the way of communicating about the quality of provided PPE and its actual quality. The promises do not meet the health care workers' expectations regarding the PPE quality,

- gap 5: the difference between how health care workers perceive their safety (safety sense) and what they received (what is the objective level of PPE quality equipment).

The SERVQUAL method based on questionnaire was created in the form of questions set related to the issues of general safety in health care institutions and personal protection of their workers. The $1^{\text {st }}$ step in preparing questionnaire was create 2 characteristic for SERVQUAL method sections. The $1^{\text {st }}$ one is containing questions connected to PPE quality assurance of health care workers' waiting. In $1^{\text {st }}$ column of table there are 20 questions connected to waiting 
of PPE. Additionally, in $2^{\text {nd }}$ column in scale 1 to 7 , health care worker marks one number. "1" means "firm not consent" and " 7 " means "firm consent" with the stated statement. The $2^{\text {nd }}$ part of the questionnaire is connected to the current state of ensuring the quality of personal protective equipment elements for healthcare workers. Similar to the $1^{\text {st }}$ part, workers mark one number. "1" means "firm not consent" and "7" means "firm consent" with the stated statement. Exampled fragments of questionnaire, both $1^{\text {st }}($ table 1$)$ and $2^{\text {nd }}$ questionnaire (table 2) was shown below.

Table 1.

Questions connected to PPE quality assurance of health care workers' waiting

\begin{tabular}{|c|c|c|c|c|c|c|c|}
\hline & \multicolumn{5}{|c|}{$\begin{array}{l}\text { Firmly } \\
\text { not consent }\end{array}$} & \multicolumn{2}{|c|}{$\begin{array}{l}\text { Firmly } \\
\text { consent }\end{array}$} \\
\hline $\begin{array}{l}\text { 1/ Employees should be regularly and scrupulously informed about } \\
\text { the possible occurrence or occurrence of infections with an infectious } \\
\text { or viral disease, both among patients and hospital staff }\end{array}$ & 1 & 2 & 3 & 4 & 5 & 6 & 7 \\
\hline 2/ The hospital should have separate hand disinfection points for staff & 1 & 2 & 3 & 4 & 5 & 6 & 7 \\
\hline $\begin{array}{l}\text { 3/ The hospital should have separate hand disinfection points for } \\
\text { employees in places particularly important from the point of view of } \\
\text { asepsis }\end{array}$ & 1 & 2 & 3 & 4 & 5 & 6 & 7 \\
\hline $\begin{array}{l}\text { 4/ Hospital authorities should provide an individual set of hand } \\
\text { washing and disinfecting fluids for each employee }\end{array}$ & 1 & 2 & 3 & 4 & 5 & 6 & 7 \\
\hline $\begin{array}{l}\text { 5/ Hospital authorities should provide access to individual items of } \\
\text { personal protection such as: gloves, masks, visors, aprons for } \\
\text { employees }\end{array}$ & 1 & 2 & 3 & 4 & 5 & 6 & 7 \\
\hline $\begin{array}{l}\text { 6/ Hospital authorities should provide a full set of individual } \\
\text { protective clothing for each employee }\end{array}$ & 1 & 2 & 3 & 4 & 5 & 6 & 7 \\
\hline $\begin{array}{l}\text { 7/ The hospital should have a place for decontamination of protective } \\
\text { suits and their reusable elements }\end{array}$ & 1 & 2 & 3 & 4 & 5 & 6 & 7 \\
\hline $\begin{array}{l}\text { 8/ The hospital should provide the possibility of decontamination of } \\
\text { protective suits, change of elements such as protective masks, visors, } \\
\text { gloves, aprons to every employee in a situation where such a need is } \\
\text { identified or in accordance with health and safety regulations and } \\
\text { hospital procedures. }\end{array}$ & 1 & 2 & 3 & 4 & 5 & 6 & 7 \\
\hline
\end{tabular}

Source: own work based on SERVQUAL Method.

Table 2.

Questions is connected to the current state of ensuring the quality of personal protective equipment elements for healthcare workers

\begin{tabular}{|c|c|c|c|c|c|c|c|}
\hline & \multicolumn{5}{|c|}{$\begin{array}{l}\text { Firmly } \\
\text { not consent }\end{array}$} & \multicolumn{2}{|c|}{$\begin{array}{c}\text { Firmly } \\
\text { consent }\end{array}$} \\
\hline $\begin{array}{l}\text { 1/ Employees are regularly and scrupulously informed about the } \\
\text { possible occurrence or occurrence of infections with an infectious or } \\
\text { viral disease, both among patients and hospital staff }\end{array}$ & 1 & 2 & 3 & 4 & 5 & 6 & 7 \\
\hline 2/ The hospital has separate hand disinfection points for staff & 1 & 2 & 3 & 4 & 5 & 6 & 7 \\
\hline $\begin{array}{l}\text { 3/ The hospital has separate hand disinfection points for employees in } \\
\text { places particularly important from the point of view of asepsis }\end{array}$ & 1 & 2 & 3 & 4 & 5 & 6 & 7 \\
\hline $\begin{array}{l}\text { 4/ Hospital authorities provide an individual set of hand washing and } \\
\text { disinfecting fluids for each employee }\end{array}$ & 1 & 2 & 3 & 4 & 5 & 6 & 7 \\
\hline $\begin{array}{l}\text { 5/ Hospital authorities provide access to individual items of personal } \\
\text { protection such as: gloves, masks, visors, aprons for employees }\end{array}$ & 1 & 2 & 3 & 4 & 5 & 6 & 7 \\
\hline $\begin{array}{l}\text { 6/ Hospital authorities provide a full set of individual protective } \\
\text { clothing for each employee }\end{array}$ & 1 & 2 & 3 & 4 & 5 & 6 & 7 \\
\hline
\end{tabular}


Cont. table 2.

\begin{tabular}{|l|l|l|l|l|l|l|l|}
\hline $\begin{array}{l}\text { 7/ The hospital has a place for decontamination of protective suits and } \\
\text { their reusable elements }\end{array}$ & 1 & 2 & 3 & 4 & 5 & 6 & 7 \\
\hline $\begin{array}{l}\text { 8/ The hospital provides the possibility of protective suits } \\
\text { decontamination, change of elements such as protective masks, } \\
\text { visors, gloves, aprons to every employee in a situation where such a } \\
\text { need is identified or in accordance with health and safety regulations } \\
\text { and hospital procedures. }\end{array}$ & 1 & 2 & 3 & 4 & 5 & 6 & 7 \\
\hline
\end{tabular}

Source: own work based on SERVQUAL Method.

The next part of questionnaire is assessment of quality assurance validity factors for health workers protection measures. A few exampled factors in form of questionnaire was shown below (table 3 ).

Table 3.

Assessment of quality assurance validity factors for health workers protection measures

\begin{tabular}{|c|c|c|c|c|c|c|c|}
\hline \multirow{2}{*}{$\begin{array}{l}\text { 1/ Provision of hand disinfectants for each employee by hospital } \\
\text { authorities }\end{array}$} & \multicolumn{5}{|c|}{$\begin{array}{l}\text { Not } \\
\text { important }\end{array}$} & \multicolumn{2}{|c|}{$\begin{array}{r}\text { Very } \\
\text { important }\end{array}$} \\
\hline & 1 & 2 & 3 & 4 & 5 & 6 & 7 \\
\hline $\begin{array}{l}\text { 2/ Provision by hospital authorities of access to individual items of } \\
\text { personal protection, such as: gloves, masks, visors, aprons for } \\
\text { employees }\end{array}$ & 1 & 2 & 3 & 4 & 5 & 6 & 7 \\
\hline $\begin{array}{l}\text { 3/ Provision by hospital authorities of a full set of individual } \\
\text { protective clothing for each employee }\end{array}$ & 1 & 2 & 3 & 4 & 5 & 6 & 7 \\
\hline $\begin{array}{l}\text { 4/ Providing the possibility of decontamination of protective suits, } \\
\text { changing elements such as protective masks, helmets, gloves, aprons } \\
\text { to each employee in a situation where such a need was identified or } \\
\text { in accordance with health and safety regulations and hospital } \\
\text { procedures }\end{array}$ & 1 & 2 & 3 & 4 & 5 & 6 & 7 \\
\hline $\begin{array}{l}\text { 5/ Regular disinfection of flat surfaces and surfaces exposed to } \\
\text { contact with people potentially suffering from viral and/or infectious } \\
\text { diseases }\end{array}$ & 1 & 2 & 3 & 4 & 5 & 6 & 7 \\
\hline
\end{tabular}

Source: own work based on SERVQUAL Method.

The $4^{\text {th }}$ part of questionnaire is the determine by the employees the frequency (in a scale from 1 to 6), of what personal protective equipment they use. A few exampled positions were shown below (Table 4).

Table 4.

Frequency of PPE usage questionnaire

\begin{tabular}{|l|c|c|c|c|c|c|c|}
\hline & \multicolumn{7}{|l}{$\begin{array}{l}\text { Vot } \\
\text { often } \\
\text { often }\end{array}$} \\
\hline Protective gloves & 1 & 2 & 3 & 4 & 5 & 6 & 7 \\
\hline Protective masks & 1 & 2 & 3 & 4 & 5 & 6 & 7 \\
\hline Face shield covers & 1 & 2 & 3 & 4 & 5 & 6 & 7 \\
\hline Protective glasses & 1 & 2 & 3 & 4 & 5 & 6 & 7 \\
\hline Aprons & 1 & 2 & 3 & 4 & 5 & 6 & 7 \\
\hline Hands Disinfectant & 1 & 2 & 3 & 4 & 5 & 6 & 7 \\
\hline
\end{tabular}

Source: own work based on SERVQUAL Method. 
The 2 last parts of questionnaire are devoted to examining employee satisfaction with the use of security measures (table 5) and supplementing the data on technical issues allowing for further statistical processing of the data (table 6).

Table 5.

Employee's satisfaction from PPE questionnaire

\begin{tabular}{|c|c|c|c|c|c|c|c|}
\hline & \multicolumn{5}{|c|}{$\begin{array}{l}\text { Firmly } \\
\text { not consent }\end{array}$} & \multicolumn{2}{|c|}{$\begin{array}{r}\text { Firmly } \\
\text { consent }\end{array}$} \\
\hline $\begin{array}{l}\text { 1/ The hospital reacts quickly to the changing epidemic situation by } \\
\text { providing employees with appropriate personal protective equipment }\end{array}$ & 1 & 2 & 3 & 4 & 5 & 6 & 7 \\
\hline $\begin{array}{l}\text { 2/ The hospital authorities guaranteed me access to personal } \\
\text { protective equipment (hand disinfectants, masks, gloves, visors, } \\
\text { protective glasses, full protective clothing, both during medical } \\
\text { procedures, operations and contact with a patient potentially infected } \\
\text { with a viral and / or infectious disease. }\end{array}$ & 1 & 2 & 3 & 4 & 5 & 6 & 7 \\
\hline 3/ Medical services in the hospital are provided in a safe manner & 1 & 2 & 3 & 4 & 5 & 6 & 7 \\
\hline $\begin{array}{l}\text { 4/ As a hospital employee, I have been informed and trained about the } \\
\text { possible occurrence or occurrence of infections with an infectious or } \\
\text { viral disease, both among patients and hospital employees. I have also } \\
\text { been acquainted with the individual procedures of dealing with such } \\
\text { a patient or person }\end{array}$ & 1 & 2 & 3 & 4 & 5 & 6 & 7 \\
\hline $\begin{array}{l}\text { 5/ I understand the procedures for individual handling of a person } \\
\text { infected with a viral and / or infectious disease }\end{array}$ & 1 & 2 & 3 & 4 & 5 & 6 & 7 \\
\hline $\begin{array}{l}\text { 6/ I can decontaminate the elements of reusable personal protective } \\
\text { equipment and change the elements of removable personal protective } \\
\text { equipment when necessary or required by health and safety } \\
\text { regulations as well as medical and hospital procedures. }\end{array}$ & 1 & 2 & 3 & 4 & 5 & 6 & 7 \\
\hline
\end{tabular}

Source: own work based on SERVQUAL Method.

\section{Table 6.}

\section{Metrics}

\begin{tabular}{|c|l|}
\hline Gender & \\
\hline MALE & \\
\hline FEMALE & \\
\hline Education & \\
\hline Basic school & \\
\hline Middle School & \\
\hline University Graduated & \\
\hline Age & \\
\hline Below & \\
\hline 20-30 & \\
\hline 30-40 & \\
\hline 40-50 & \\
\hline Up to 50 & \\
\hline Role at work & \\
\hline Type of medical facility & \\
\hline Public/Private medical facility & \\
\hline (please choose and mark correct answer) & \\
\hline City & \\
\hline
\end{tabular}

Source: own work based o SERVQUAL Method. 
Having a prepared questionnaires and knowledge about GAP model adopted to research in PPE quality for health care workers it is necessary to establish a path of action for the implementation of further researches. One of exampled path can be based on directing a requests to the owners or management of health care facilities. then, if consent is obtained, it is possible to deliver questionnaires to the facility by post or by e-mail in order to conduct the survey. The next step is complete the surveys by health care workers and give it back. The collected questionnaires should back to surveyors. Proposition of such path was shown below in a graphic manner.

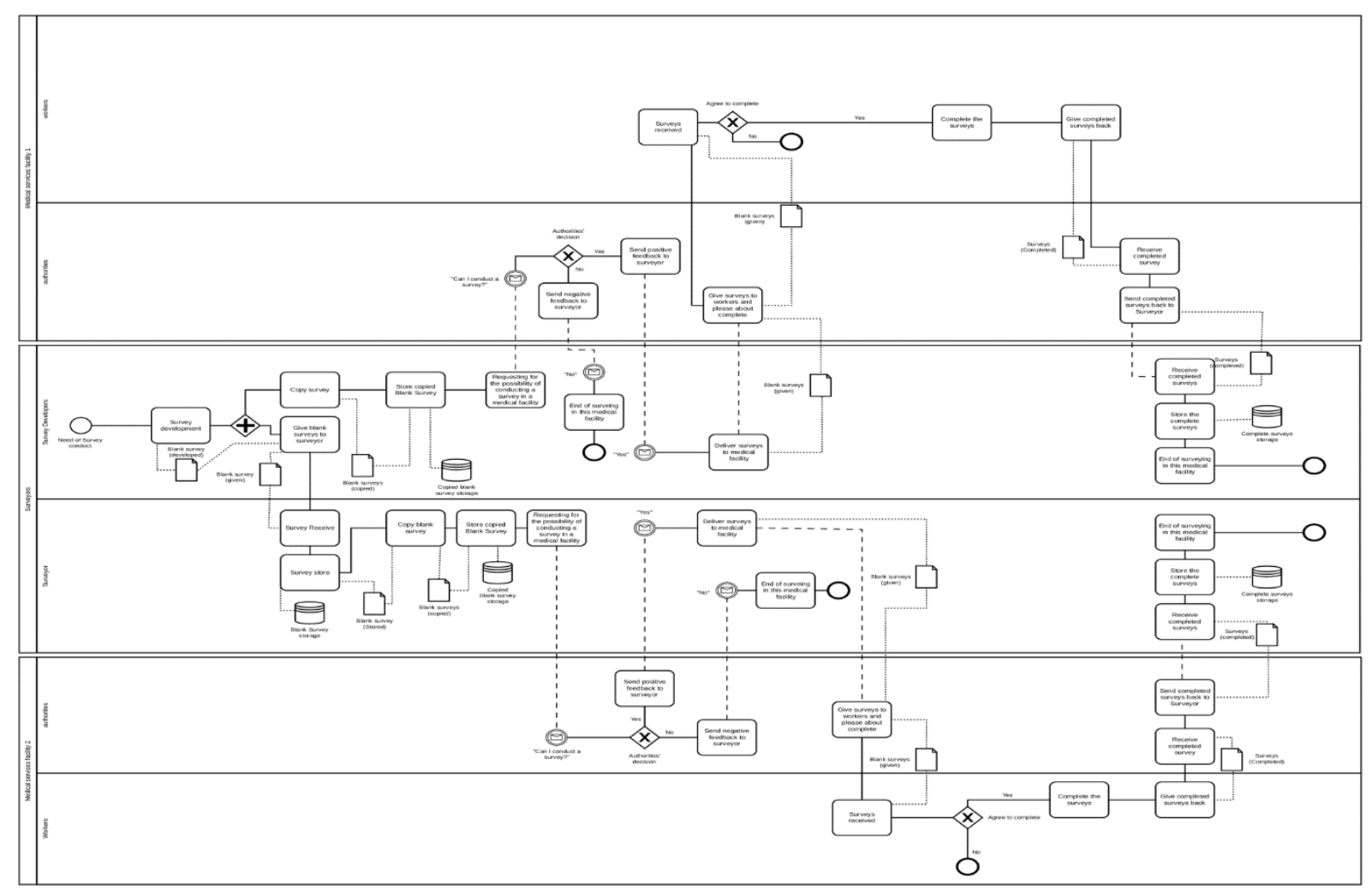

Figure 3. Proposition of further research path in order to created surveys. Source: Author's own work based on the BPMN 2.0 standard.

\section{Summary}

The article presented above shows the possibility of adopting the SERVQAL method as an important component of examining the quality of PPE for health care workers in Polish medical facilities. Not only give it a possibility to examine it, but also allow us meet health care workers' opinion what is most and less important in created and presented statements. It becomes the basis for carrying out more extensive statistical research allowing to determine and assess the quality level of health care workers' PPE in Polish health care facilities. This is of particular importance in times of the COVID-19 pandemic. Main findings from this paper are: 
- the questionnaire based on SERVUQAL method for further researches was created and its parts was shown in tables,

- created questionnaire is useful and can be a part of complex researches on PPE quality level assessment in Polish health care facilities. Due to this, created questionnaire can be helpful to analyze and asses factors and level of quality assurance of health care workers' personal protective equipment (PPE),

- owing to a GAP Method, the 5 gaps in delivering PPE to health care workers were discovered,

- ohis questionnaire can be implicate in broader understood improvement of health care workers' personal protective equipment quality,

- the exampled path of further researches was presented and described.

\section{References}

1. Abramov, S.S. (2011). Оценка качества услуг с учетом позиции потребителя. Вестник Адыгейского государственного университета, 5.1, 215-221.

2. Banahene, S., Ahudey, E., Asamoah A. (2017). Analysis of SERVQUAL Application to Service Quality Measurement and Its Impact on Loyalty in Ghanaian Private Universities. Journal of Management and Strategy, 8.4, 10.5430/jms.v8n4p18.

3. Chang, Ch., Chen, S., Lan, Y. (2013) Service quality, trust, and patient satisfaction in interpersonal-based medical service encounters. BMC Health Services Research, 13.22.

4. Gronroos, Ch. (1988). The six criteria of good perceived Service Quality. Review of Business, 9, 3, 10-13.

5. Guerguis, A. (2018). The gaps model of service quality and Customer Relationships in a digital marketing context. Manchester: University of Salford.

6. Hamrol, A., Manutra, W. (2002). Zarzadzanie jakością. Teoria i praktyka. Warszawa: PWN.

7. Hizam, S.M., Waqas, A. (2019). A Conceptual Paper on SERVQUAL-Framework for Assessing Quality of Internet of Things (IoT) Services. International Journal of Financial Research, 10.5 .

8. Hsu, J., Kalesnik, V., Kose, E. (2018). What is Quality? Financial Analysts Journal, 75, 2, 44-61, doi:10.1080/0015198X.2019.1567194.

9. Kaldenberg, D., Becker, B.W., Browne, B.A., Browne, W.G. (1997). Identifying service quality strengths and weaknesses using SERVQUAL: a study of dental services. Health Mark Q., 15, 2, 69-86, doi:10.1300/j026v15n02_04.

10. Kar, B. (2018). Service Quality and SERVQUAL Model: A Reappraisal. Amity Journal of Operations Management, 1.2, 52-64. 
11. Ko, Ch., Chou, Ch. (2020). Apply the SERVQUAL Instrument to Measure Service Quality for the Adaptation of ICT Technologies: A Case Study of Nursing Homes in Taiwan. Healthcare, 8, 108, 1-16, doi:10.3390/healthcare8020108

12. Lesatri, R., Setyawan, F.E.B. (2018) Medical staff services quality to patients satisfaction based on SERVQUAL dimensions. International Journal of Public Health Science (IJPHS), 8.1, 51-57.

13. Parasuraman, A., Berry, L.L., Zeithaml, V.A.F. (1991). Refinement and Reassessment of the SERVQUAL Scale. Journal of Retailing, 67.4, 420-450.

14. Prentkovskis, O., Erceg, Ž., Stević, Ž., Tanackov, I., Vasiljević, M., Gavranović, M. (2018). A new methodology for improving service quality measurement: Delphi-FUCOMSERVQUAL model. Symmetry, 10.757, doi:10.3390/sym10120757.

15. Stasiak-Betlejewska, R., Kaye, M., Dyason, M., Stachová, K., Urbancová, H. (2014). The Services Quality level assessment at the technical university using the SERVQUAL method. ERIES Journal, 7.3-4, 53-58, doi:10.7160/eriesj.2014.070302.

16. Sunindijo, R.Y., Bonaventura, H.W.H. (2014). Modelling service quality in the construction industry. International Journal of Business Performance Management, 15.3, 262-276.

17. Tavakoli, N., Yadegarfar, G., Bagherian, H., Ghasri, F. (2019). Assessing the educational services quality of health information technology students. J. Edu. Health Promot., 8, 168.

18. Urbaniak, A.M. (2013). Zastosowanie metody SERVQUAL do oceny jakości usług rekreacyjnych. ZNUV, 32, 29-38.

19. Wolniak, R. (20010). Pomiar oczekiwanej i postrzeganej jakości w usługach medycznych, Wspótczesne Zarządzanie, 2, 128-140.

20. Wolniak, R., Skotnicka-Zasadzień, B. (2009). Wykorzystanie metody SERVQUAL do badania jakości usług w administracji samorządowej. Gliwice: Wydawnictwo Politechniki Śląskiej. 